OPEN ACCESS

Edited by:

Qingli Dong,

University of Shanghai for Science and Technology, China

Reviewed by:

Learn-Han Lee,

Monash University Malaysia, Malaysia

Dapeng Wang,

Shanghai Jiao Tong University, China

${ }^{*}$ Correspondence:

Yong Zhao

yzhao@shou.edu.cn

${ }^{\dagger}$ These authors have contributed equally to this work.

Specialty section: This article was submitted to

Food Microbiology,

a section of the journal

Frontiers in Microbiology

Received: 09 May 2018

Accepted: 12 July 2018

Published: 02 August 2018

Citation:

Niu B, Hong B, Zhang Z, Mu L, Malakar PK, Liu H, Pan Y and Zhao Y

(2018) A Novel aPCR Method

for Simultaneous Detection and Quantification of Viable

Pathogenic and Non-pathogenic

Vibrio parahaemolyticus $\left(t / h^{+}, t d h^{+}\right.$ and ure $R^{+}$). Front. Microbiol. 9:1747.

doi: 10.3389/fmicb.2018.01747

\section{A Novel qPCR Method for Simultaneous Detection and Quantification of Viable Pathogenic and Non-pathogenic Vibrio parahaemolyticus $\left(t / h^{+}, t d h^{+}\right.$, and ure $^{+}$)}

\author{
Ben Niu't , Bin Hong ${ }^{1+}$, Zhaohuan Zhang ${ }^{1+}$, Lili Mu ${ }^{1}$, Pradeep K. Malakar', \\ Haiquan Liu ${ }^{1,2,3,4}$, Yingjie Pan ${ }^{1,2,3}$ and Yong Zhao ${ }^{1,2,3 *}$
}

\begin{abstract}
${ }^{1}$ College of Food Science and Technology, Shanghai Ocean University, Shanghai, China, ${ }^{2}$ Laboratory of Quality and Safety Risk Assessment for Aquatic Products on Storage and Preservation, Ministry of Agriculture, Shanghai, China, ${ }^{3}$ Shanghai Engineering Research Center of Aquatic-Product Processing and Preservation, Shanghai, China, ${ }^{4}$ Engineering Research Center of Food Thermal-processing Technology, Shanghai Ocean University, Shanghai, China
\end{abstract}

Pathogenic and non-pathogenic Vibrio parahaemolyticus strains were simultaneously detected and quantified using a novel viable multiplex real-time PCR (novel qPCR). We used a new PCR primer and probe, ureR, as a surrogate for detection of the toxin trh gene as the primer was better at identifying variant $V$. parahaemolyticus trh strains. The specificity of all primers and probes used in this study were validated on three standard strains of $V$. parahaemolyticus, 42 clinical strains, 12 wild strains, 4 strains of Vibrio spp., and 4 strains of other bacteria. Then, propidium monoazide (PMA) was applied to inhibit DNA of dead cell, and the results of PMA optimized treatments were $15 \mu \mathrm{M}$ concentration, 5 min incubation periods, 15 min light exposure periods and 30 RPM rotational speed, which resulted in time and cost savings. Pathogenic and non-pathogenic strains were quantified using a two-reaction tube method where the $t / h, t d h$, and ureR genes were amplified. Additionally, standard curves with a 7-log dynamic range were generated for quantifying viable $V$. parahaemolyticus and the amplification efficiencies were 108.68, 105.17, and $115.61 \%$ for $t / h^{+}, t d h^{+}$, and ureR $^{+}$. This novel qPCR accurately monitored $V$. parahaemolyticus contamination rates in shrimps (Penaeus vannamei) and clams (Ruditapes philippinarum) sampled from retail stores located in a major district in Shanghai. In conclusion, our assay can prioritize the detection and quantification of viable pathogenic $V$. parahaemolyticus and can prove to be a more effective tool for reducing infection risks from consumption of seafood in Shanghai.

Keywords: novel qPCR, PMA, pathogenic and non-pathogenic V. parahaemolyticus, rapid detection technique, shrimp, clam 


\section{INTRODUCTION}

Vibrio parahaemolyticus is a gram-negative and halophilic pathogen which was identified in the 1950s (Shinoda, 2011). This bacterium is widely distributed in the marine and estuarine environment (Bej et al., 1999) and is a major food borne pathogen in China and South East Asia countries ( $\mathrm{Su}$ and Liu, 2007; Zhang et al., 2015a). It is the common cause of gastrointestinal disease from consumption of raw or lightly cooked seafood (Letchumanan et al., 2015; Eschbach et al., 2017). The $V$. parahaemolyticus virulence factors contributing to disease include adhesin, thermostable direct hemolysin (TDH), TDH related hemolysin (TRH), 2 type III secretion systems (T3SS1 and T3SS2) and 2 type VI secretion systems (T6SS1 and T6SS) (Ceccarelli et al., 2013; Wang R. et al., 2015). TDH and TRH are considered the major virulence factors: the $t d h$ gene, a $567 \mathrm{bp}$, was cloned and determined by Kaper et al. (1984) and the trh gene was determined by Hondo et al. $(1987,1988,1989)$. There are five variants of the $t d h$ gene $(t d h 1, t d h 2, t d h 3, t d h 4, t d h 5)$ and these variants share $97 \%$ sequence identity (Nishibuchi and Kaper, 1990), while two variants of trh gene (trh1, trh2) only show $84 \%$ sequence identity (Nishibuchi et al., 1989; Bisha et al., 2012) and the toxins expressed by $t r h 1$ and $t r h 2$ are related to toxins expressed by $t d h$ (Ceccarelli et al., 2013; Nilsson and Turner, 2016). The lack of sequence identity of the trh gene and the relatedness of the hemolysin toxins can lead to classification errors. A useful surrogate for trh is the urease gene cluster ure $\mathrm{R}$. The ure $\mathrm{R}$ gene cluster is immediately upstream of trh and using this cluster can circumvent challenges associated with trh variation (Suthienkul et al., 1995; Nilsson and Turner, 2016).

Rapid detection technique can improve the management of microbial food safety and lots of detection methods were developed for $V$. parahaemolyticus (Nordin et al., 2017; Wu et al., 2018; Yang et al., 2018). Standard detection for $V$. parahaemolyticus, which is time and labor intensive, consists of isolation, purification and identification based on thiosulfatecitrate-bile-salts-sucrose (TCBS) agar and Polymerase Chain Reaction (PCR) (Niu et al., 2018). This method, however, fails to detect viable but non-culturable (VBNC) cells and $V$. parahaemolyticus has been shown to easily enter VNBC state as a response to adversity (Coutard et al., 2007). The VBNC cell loses the ability to divide but maintains metabolic, gene expression, antibiotic resistance, and pathogenic properties. Nevertheless, this cell can regain its normal culturable state given the right circumstances. Current $V$. parahaemolyticus detection is also unable to discriminate pathogenic from non-pathogenic $V$. parahaemolyticus which can be important from a food safety perspective. PCR assays were developed for the detection of $V$. parahaemolyticus to overcome the shortcomings above and these assays include the real-time qPCR and multiplex qualitative PCR (multi-qPCR) (Xiao et al., 2015; Zhang et al., 2015a). However, qPCR and multi-qPCR generates high false-positive rates due the persistence of DNA after cell death and therefore overestimates infection risks.

There are two major approaches for reducing false-positive rates caused by residual DNA from dead cells. The first approach is real-time reverse-transcriptase $\mathrm{qPCR}$ where $\mathrm{CDNA}$ is reverse transcribed by RNA (Gonzálezescalona et al., 2009; Miller et al., 2011; Ye et al., 2012). However, RNA extraction is difficult and the rapid degradation of RNA limits its wider application (Bleve et al., 2003; Morin et al., 2004). The other approach is the coupling of qPCR with nucleic acid dyes, ethidium monoazide (EMA) and propidium monoazide (PMA) (Salam et al., 2014; Li et al., 2015; Wang L.J. et al., 2015). In non-viable cells, these nucleic acid dyes selectively penetrate and covalently bind to genomic DNA after photoactivation. PMA is a better dye as EMA is known to also bind to the DNA of viable cells (Kobayashi et al., 2009; Yang et al., 2011; Fittipaldi et al., 2012) and PMA-qPCR is the preferred method for distinguishing viable from non-viable cells (Lee and Levin, 2009; Yang et al., 2011; Fittipaldi et al., 2012).

The $t$ lh gene is present in both pathogenic and non-pathogenic $V$. parahaemolyticus strains while the $t d h$ and trh gene are only present in pathogenic strains. In this study we take into account of the presence of the $t h, t d h$, and trh gene by using a two-reaction tube system where one reaction tube only detects the th gene and the second tube only detects the $t d h$ and $t r h$ genes.

The objective of this study is to establish a novel qPCR method for simultaneous detection and quantification of viable pathogenic $\left(t h^{+}, t d h^{+}\right.$, and $\left.u r e \mathrm{R}^{+}\right)$and non-pathogenic $\left(t h^{+}\right.$, $t d h^{-}$, and $u r e \mathrm{R}^{-}$) V. parahaemolyticus strains. The precision, practicability and robustness of this novel-qPCR method will be compared to the standard method of detection and the novel qPCR method will be used to monitor the $V$. parahaemolyticus contamination rates in retail store samples from a major district in Shanghai.

\section{MATERIALS AND METHODS}

\section{Bacteria Strain and Preparation of Inoculum}

The 65 bacterial strains used in this study were listed in Table 1. $V$. parahaemolyticus strains were grown in $9 \mathrm{~mL}$ tryptic soy broth (TSB; Beijing Land Bridge Technology Company Ltd., Beijing, China) with $3 \%(\mathrm{w} / \mathrm{w})$ sodium chloride $(\mathrm{NaCl})$ and incubated at $37^{\circ} \mathrm{C}$ for $16-18 \mathrm{~h}$, and other strains were grown in $9 \mathrm{~mL}$ TSB at $37^{\circ} \mathrm{C}$ for $18-20 \mathrm{~h}$ to get approximately $9 \mathrm{Log} \mathrm{CFU} / \mathrm{g}$.

\section{Preparation of Dead V. parahaemolyticus}

V. parahaemolyticus ATCC $33847\left(t d h^{+}\right)$, ATCC $17802\left(t r h^{+}\right)$, and VP1 $\left(t h^{+}\right)$were inoculated in $\mathrm{TSB}^{+}$(TSB with $3 \%(\mathrm{w} / \mathrm{w})$ $\mathrm{NaCl}$ ) at $37^{\circ} \mathrm{C}$ for $12-18 \mathrm{~h}$. Then bacteria suspensions were transferred to $10 \mathrm{~mL}$ sterile centrifuge tubes at $3,000 \times g$ for $10 \mathrm{~min}$ at $25^{\circ} \mathrm{C}$, respectively. Afterward, the density of the bacterial suspensions was measured by BioTek Synergy2 (Winooski, VT, United States) at $600 \mathrm{~nm}\left(\mathrm{OD}_{600 \mathrm{~nm}}\right)$. When the $\mathrm{OD}_{600 \mathrm{~nm}}$ values of $V$. parahaemolyticus are in the interval (1.2, 1.3), the bacteria concentrations are $9 \log _{10} \mathrm{CFU} / \mathrm{g}$ (Niu et al., 2018). Dead cells were obtained by heating suspensions at $85^{\circ} \mathrm{C}$ for $30 \mathrm{~min}$.

\section{Optimization of PMA Treatment}

Propidium monoazide (PMA) (Biotium, Hayward, CA, United States) stock solution (2 $\mathrm{mM}$ ) was obtained by dissolving 
TABLE 1 | Specificity of the novel qPCR amplification of th, tdh, and ureR target genes in $V$. parahaemolyticus.

\begin{tabular}{|c|c|c|c|c|c|}
\hline \multirow[t]{2}{*}{ Bacterial Species } & \multirow[t]{2}{*}{ Strains } & \multirow{2}{*}{$\begin{array}{l}\text { No. of } \\
\text { Strains }\end{array}$} & \multicolumn{3}{|c|}{ PCR results } \\
\hline & & & $t / h^{+}$ & $t d h^{+}$ & $t r h^{+}$ \\
\hline \multirow[t]{7}{*}{ V. parahaemolyticus } & ATCC 33847 & 1 & + & + & - \\
\hline & ATCC 33846 & 1 & + & + & - \\
\hline & ATCC 17802 & 1 & + & - & + \\
\hline & V. pc-A & 3 & + & + & + \\
\hline & V. pc-B & 4 & + & - & + \\
\hline & V. pc-C & 34 & + & + & - \\
\hline & V. pc-D & 1 & + & - & - \\
\hline V. vulnificus & Wild type from shrimp & 12 & - & - & - \\
\hline V. fluvialis & CGMCC 1.1611 & 1 & - & - & - \\
\hline V. anguillarum & CICC 10475 & 1 & - & - & - \\
\hline V. vulnificus & MCCC $1 \mathrm{H} 00066$ & 1 & - & - & - \\
\hline V. cholera & GIM1.449 & 1 & - & - & - \\
\hline L. monocytogenes & ATCC 19112 & 1 & - & - & - \\
\hline S. Typhimurium & ClCC 21484 & 1 & - & - & - \\
\hline E. coli O157:H7 & ATCC 43889 & 1 & - & - & - \\
\hline S. aureus & ССТСС АВ 91093 & 1 & - & - & - \\
\hline
\end{tabular}

List of the bacteria information. 1. The gene information of V. pc-A, V. pc-B, V. pc-C, and V. pc-D were certified by Li et al. (2017), see Supplementary Table S1 for more information. 2. ATCC, America Type Culture Collection; USA, CICC, China Center of Industrial Culture Collection; CGMCC, China General Microbiological Culture Collection Center; CCTCC, China Center for Type Culture Collection); MCCC, Marine Culture Collection of China; "+/-" indicated the negative and positive results of PCR, respectively.

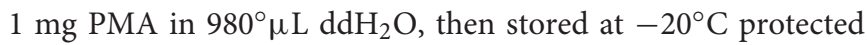
from light. All the optimization treatments were carried out with the new machine designed by Zhang et al. (unpublished). To optimize the treatment of PMA, both dead and viable cells (approximately $8 \log _{10} \mathrm{CFU} / \mathrm{g}$ ) were subjected to PMA treatment where five concentrations of PMA $(10,15,25,50$, or $\left.100^{\circ} \mu \mathrm{M}\right)$, five incubation periods $(5,10,15,20$, or $30 \mathrm{~min})$, and seven light exposure periods $(5,10,15,20,25,30$, or $40 \mathrm{~min})$, and six rotation rates $(10,20,30,40,50$, or $60 \mathrm{RPM})$ were tested.

\section{DNA Extraction}

Bacterial DNA was extracted by using the TIANamp Bacteria DNA Kit (Tiangen Biotech Beijing Co., Ltd., Beijing, China) according to the manufacturer's instruction, whereas modification was made: DNA was eluted from adsorption column twice by adding $100 \mu \mathrm{L}$ (one-time $50 \mu \mathrm{L}$ ).

\section{qPCR and Standard Curves}

All primers and probes were synthesized by Invitrogen Corp (Shanghai, China) unless otherwise stated. TaqMan primers and probes used in this study for detection and quantification of $V$. parahaemolyticus were listed in Table 2. The novel method was carried out in a final volume of 20:2 $\mu \mathrm{L}$ of $10 \times$ PCR Buffer (Invitrogen, United States), $1.2 \mu \mathrm{L}$ of $50 \mathrm{mM} \mathrm{Mg}^{+}$(Invitrogen, United States), $0.5 \mu \mathrm{L}$ of $10 \mathrm{mM}$ dNTPs mix (Invitrogen, United States), $0.5 \mu \mathrm{L}$ of $10 \mu \mathrm{M}$ primer, $0.2 \mu \mathrm{L}$ of Taq DNA polymerase $(5 \mathrm{U} / \mu \mathrm{L})$ (Invitrogen, United States), and $0.2 \mu \mathrm{L}$ of $10 \mu \mathrm{M}$ probe were used for each strain; $1 \mu \mathrm{L}$ of DNA were
TABLE 2 | TaqMan primers and probe sequences used in this study.

\begin{tabular}{|c|c|c|c|}
\hline $\begin{array}{l}\text { Primer/ } \\
\text { probe }\end{array}$ & Sequence, $5^{\prime}-3^{\prime}$ & Target & References \\
\hline$t / h-\mathrm{F}$ & ACTCAACACAAGAAGAGATCGACAA & th & $\begin{array}{l}\text { Nordstrom } \\
\text { et al., } 2007\end{array}$ \\
\hline thh-R & GATGAGCGGTTGATGTCCAA & th & \\
\hline thh-P & VIC/CGCTCGCGTTCACGAAACCGT/BHQ1 & 1 t/h & \\
\hline$t d h-\mathrm{F}$ & тссстाтсстGссссC & $t d h$ & $\begin{array}{l}\text { Nordstrom } \\
\text { et al., } 2007\end{array}$ \\
\hline$t d h-\mathrm{R}$ & CGCTGCCATTGTATAGTCTITATC & $t d h$ & \\
\hline$t d h-P$ & NED/TGACATCCTACATGACTGTG/MGB & $t d h$ & \\
\hline ureR-Fa & GCGTAGTCATCGTTCCGAAATAC & trh & $\begin{array}{l}\text { Nilsson and } \\
\text { Turner, } 2016\end{array}$ \\
\hline ureR-R $R^{a}$ & AAGTGAGCCTCCATTGATTGTAGAG & trh & \\
\hline ureR-pa & $\begin{array}{l}\text { FAM/TCGCGTATC/ZEN/CTGCACTCTA } \\
\text { ACACCCA/3IABKFQ/ }\end{array}$ & trh & \\
\hline
\end{tabular}

asynthesized by Integrated DNA Technologies, Coralville, IA.

used as template. A Quant Studio ${ }^{\mathrm{TM}} 6$ Flex Real-Time PCR system (Applied Biosystems, Foster City, CA, United States) was used with the following thermal profile: initial denaturation of genomic DNA at $95^{\circ} \mathrm{C}$ for $1 \mathrm{~min}$, followed by 40 cycles of denaturation at $95^{\circ} \mathrm{C}$ for $5 \mathrm{~s}$, and annealing at $59^{\circ} \mathrm{C}$ for $45 \mathrm{~s}$.

Even for the same target bacteria, some studies have shown that the PCR effect would be still influenced by different target genes or different target sequence lengths (Chang et al., 2010; Soejima et al., 2011; Li and Chen, 2013). Additionally, Anand Løvdal found that the optimization of PMA would also be affected by different proportion of dead and viable bacteria (Pan and Breidt, 2007; Løvdal et al., 2011). Therefore, three target genes $t h, t d h$, ure $\mathrm{R}$ were optimized in different proportion of dead and viable bacteria to obtain the optimization treatments: (1) viable cell (approximately $2-7 \log _{10} \mathrm{CFU} / \mathrm{g}$ ) without PMA treatment; (2) Mixed bacteria solution (for example: $1 \mathrm{~mL} 9$ $\log _{10} \mathrm{CFU} / \mathrm{g}$ dead cell and $1 \mathrm{~mL} 8 \log _{10} \mathrm{CFU} / \mathrm{g}$ viable cell were added into $8 \mathrm{~mL}$ TSB to get the mixed bacteria solution $\left(8 \log _{10}\right.$ $\mathrm{CFU} / \mathrm{g}$ dead cell and $7 \log _{10} \mathrm{CFU} / \mathrm{g}$ ), then diluted to get the required mixed bacteria solution): viable cell (approximately 2-7 $\log _{10}$ CFU/g) and dead cell (approximately 3-8 $\log _{10}$ CFU/g) without PMA treatment; (3) Mixed bacteria solution: viable cell (approximately 2-7 $\log _{10} \mathrm{CFU} / \mathrm{g}$ ) and dead cell (approximately 3-8 $\log _{10}$ CFU/g) with PMA treatment; (4) Mixed bacteria solution: viable cell (approximately $2-7 \log _{10} \mathrm{CFU} / \mathrm{g}$ ) and dead cell (approximately 1-6 $\log _{10} \mathrm{CFU} / \mathrm{g}$ ) with PMA treatment. Then the optimized proportion of dead and viable bacteria was set for the standard curve.

\section{Validation of the Novel qPCR}

In order to evaluate the robustness of this assay, V. parahaemolyticus VP1 $\left(t h^{+}\right)$, ATCC $33847\left(t d h^{+}\right)$, and ATCC $17802\left(t r h^{+}\right)$were employed to assess the target gene $t l h, t d h$, and $u r e \mathrm{R}$, respectively. As for $V$. parahaemolyticus VP1 $\left(t h h^{+}\right)$, approximately $9 \log _{10} \mathrm{CFU} / \mathrm{g}$ was obtained by measured the $\mathrm{OD}_{600}$ value in the interval $[1.2,1.3]$. Afterward, it was diluted and inoculated into the $9 \mathrm{~mL} \mathrm{TSB}^{+}$medium to achieve the cell concentration with 2-8 $\log _{10} \mathrm{CFU} / \mathrm{mL}$, and then 
plated the bacteria solution on TCBS agar at $37^{\circ} \mathrm{C}, 48 \mathrm{~h}$, in the meantime, $1 \mathrm{~mL}$ bacteria solution were transferred to $1.5 \mathrm{~mL}$ centrifuge tube for qPCR. Both ATCC $33847\left(t d h^{+}\right)$, and ATCC $17802\left(\mathrm{trh}^{+}\right)$were enumerated and validated in this way.

\section{Detection of Practical Samples}

Shrimp (Penaeus vannamei) and clam (Ruditapes philippinarum) were purchased from various regions of Shanghai, including Baoshan District, Jiading District, Main urban District, Qingpu District, Songjiang District, Minhang District, Jinshan District, Fengxian District, and Pudong New Area (this Area is divided into the northern region and southern region, Nanhui New Area). The water samples of shrimp (Penaeus vannamei) and clam (Ruditapes philippinarum) were collected and put into empty Nongfu Spring bottle at the same time. All the samples were stored in the mobile refrigerator and transported to the laboratory in time, processed in $24 \mathrm{~h}$, and then stored at $-80^{\circ} \mathrm{C}$.

The whole shrimp and the whole clam tissue were placed in the biological safety cabinet and weighed by scales. Twenty five were added into $225 \mathrm{~mL} 0.1 \%$ aseptic Peptone Water $(\mathrm{PW})$. Then they were homogenized in a stomacher (Bag Mixer 400VW, Interscience, France) for $2 \mathrm{~min}$ and $2 \mathrm{~mL}$ homogenate were transferred into $5 \mathrm{~mL}$ centrifuge tube for $1 \min \left(200 \times g, 4^{\circ} \mathrm{C}\right), 1 \mathrm{~mL}$ supernatant transferred into $1.5 \mathrm{~mL}$ centrifuge tube $\left(2 \mathrm{~min}, 12,000 \times \mathrm{g}, 4^{\circ} \mathrm{C}\right)$ for DNA extraction (according to the manipulation above). Water sample were filtered from nitrocellulose filter membrane (Millipore, Billerica, MA, United States) by the vacuum pump (Millipore, Billerica, MA, United States), afterward, the bacteria were washed by $\mathrm{ddH}_{2} \mathrm{O}$ from filter membrane for PMA treatments prior to DNA extraction (Fast DNA Spin Kit for Soil, Millipore, Billerica, MA, United States). And all the DNA were stored at $-80^{\circ} \mathrm{C}$. All experiments in this study were repeated three times independently.

\section{RESULTS}

\section{Specificity of Primers and Probes}

The specificity of this method was tested by 65 strains (Table 1), of which there were three standard strains of $V$. parahaemolyticus, 42 strains of clinical $V$. parahaemolyticus (see Supplementary Table S1), 12 strains of wild $V$. parahaemolyticus, 4 strains of Vibrio spp., and four strains other bacteria. As shown in Table 1, all the tested $V$. parahaemolyticus were positive for $t$ lh. The $t d h$ and $t r h$ independent strains only showed positive signals for $t d h$ and $u r e \mathrm{R}$ fluorescent probe, respectively. All non-target strains were negative for $t h$, $t d h$, and $u r e \mathrm{R}$ fluorescent probe, which indicated the high specificity of this method.

\section{PMA Optimization}

As shown in Figure 1A, the horizontal coordinate was PMA concentration with $10,15,25,50$, and $100 \mu \mathrm{M}$, respectively. And vertical coordinate was the average difference value of $\mathrm{Ct}$ that is result of $\mathrm{Ct}$ value of the viable cell without PMA treatment minus the Ct value of the same concentration dead cell with PMA treatment. There was no significant difference $(p<0.05)$ between
15 and $25 \mu \mathrm{M}$ of PMA concentration. While the concentration was more than $25 \mu \mathrm{M}$, the effect even became worse. Figure 1B is a schematic effect on incubation. There was no significant difference $(p<0.05)$ between 5 and $10 \mathrm{~min}$ of incubation time, so $5 \mathrm{~min}$ was selected as the incubation treatment. For light exposure, the treatment effect did not decrease until $20 \mathrm{~min}$ $(p<0.05)$ (Figure 1C), so the shorter time of $15 \mathrm{~min}$ was selected as the light exposure. In addition, the rotation on treatment effect was addressed for the first time. Figure 1D is a diagram of rotation treatment, and $30 \mathrm{RPM}$ was chosen as best rotation rate.

Moreover, in order to avoid the possible inhibition of PMA on viable cell, viable cell experiments on the same conditions were conducted. The result was shown in Supplementary Figure S1. All data indicate that the optimization conditions were $15 \mu \mathrm{M}$ PMA concentration, $5 \mathrm{~min}$ incubation time, $15 \mathrm{~min}$ light exposure, and $30 \mathrm{RPM}$ rotation rate.

\section{Standard Curve}

As shown in Figure 2, $t l h, t d h$, and $u r e \mathrm{R}$ were treated with different concentration ratio of dead and viable cell, respectively. Results showed that the PMA modification effect was most close to the DNA amplification of viable cell, when the concentration of dead bacteria was less than viable cell by $1 \mathrm{Ct}$. So, we chose this concentration ratio of viable and dead cell for future standard curve.

Based on PMA optimization and concentration ratio of dead and viable cell above, the constructed standard curves of $t h, t d h$, and $u r e \mathrm{R}$ were shown in Figure 3. Results showed that $R^{2}$-value was $0.994,0.999$, and 0.997 for $t h, t d h$, and $u r e \mathrm{R}$, and the slopes of the three standard curves were $-3.130,-3.204$, and -2.997 , respectively. The amplification efficiency $\left(E=10^{-1 / \text { slope }_{-}}-1\right)$ of the corresponding PCR calculated in this method were 108.68, 105.17 , and $115.61 \%$, respectively. The results indicated that the novel qPCR reaction system had good amplification efficiency and was suitable for further analysis.

\section{Validation of the Novel qPCR}

After the validation of specificity, limit of detection (LOD) and amplification efficiency of the method, we compared this novel method with the standard method. In order to evaluate the efficiency of the novel qPCR's detection and quantification capability of viable pathogenic and non-pathogenic $V$. parahaemolyticus, a series of 10 -fold bacteria dilutions $\left(10^{2}-10^{8} \mathrm{CFU} / \mathrm{g}\right)$ were enumerated by both novel and the standard method. As shown in Table 3, the result of th counted from TCSB was agreed the PCR results with approximately $10^{2}-10^{8} \mathrm{CFU} / \mathrm{g}(p<0.05)$. Thus, comparing to traditional plate counting method, the results demonstrated that our novel qPCR provided a robust and efficient means for the detection and quantification of nonpathogenic $V$. parahaemolyticus. The same conclusions could easily be drawn for both $t d h$ and ureR from Table 3 .

\section{Practical Samples Detection}

In order to ensure the detection accuracy of the practical sample, PCR inhibition control in all the samples were conducted (Supplementary Figure S2). And vertical coordinate was average 

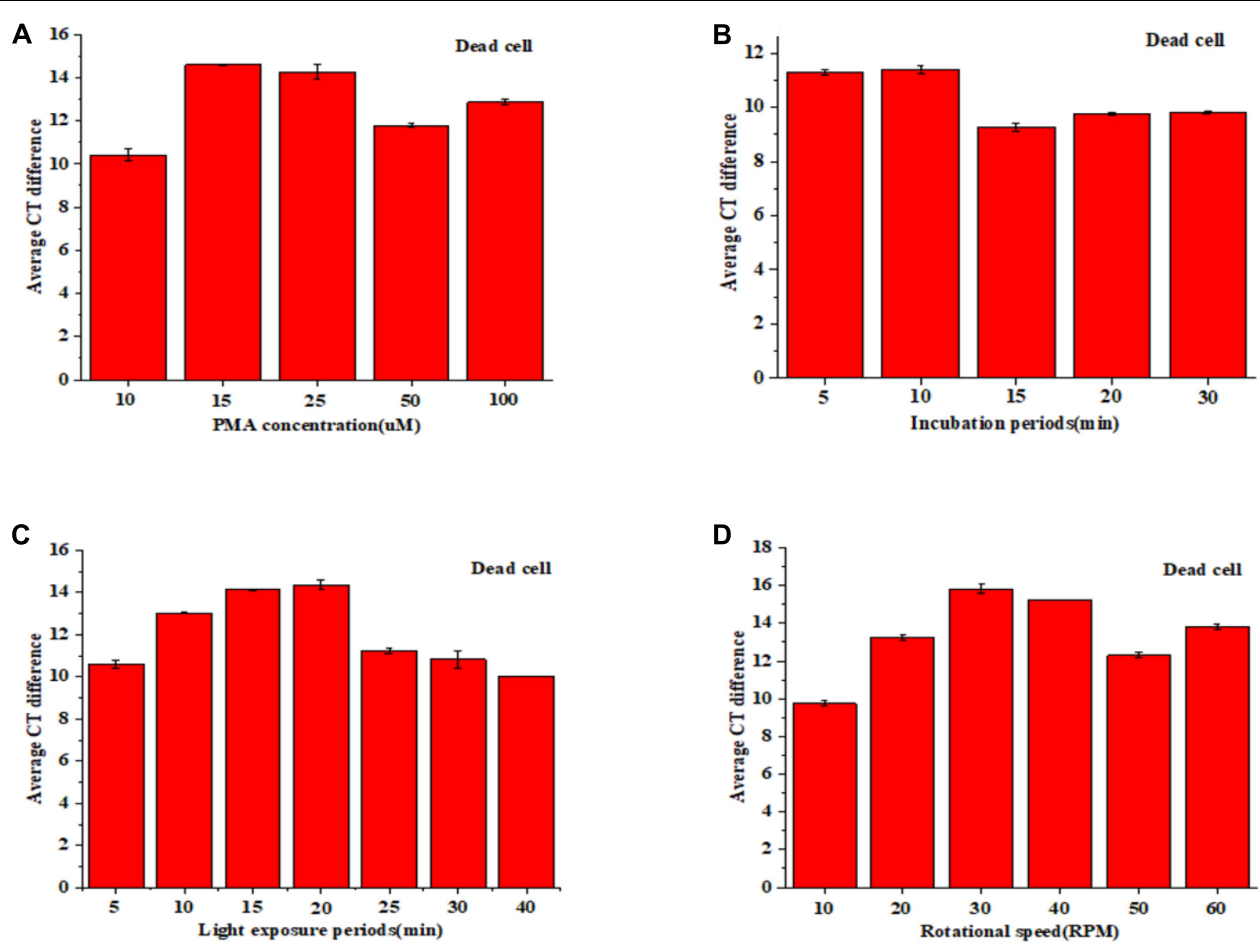

FIGURE 1 | PMA pretreatment on dead cell: concentration (A), incubation time (B), light exposure (C), and rotation rate (D).

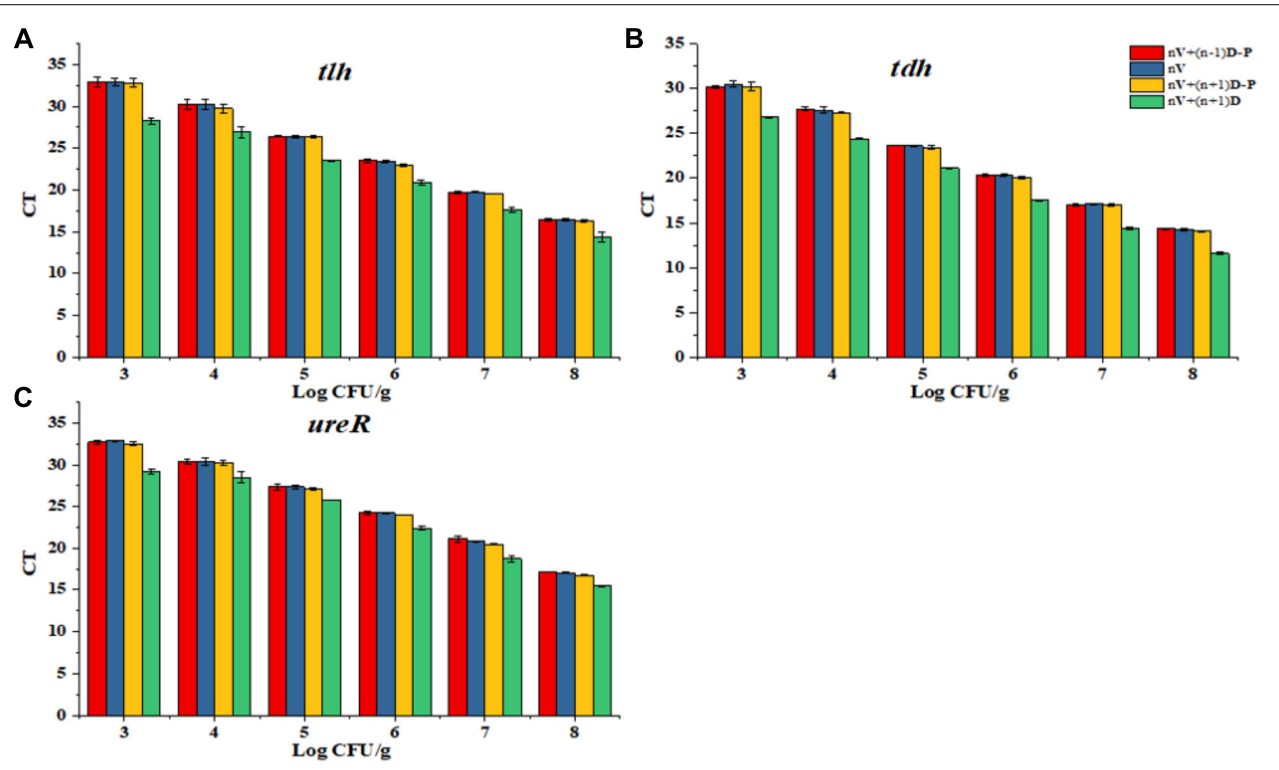

FIGURE 2 | Determination of the proportion of dead and viable cell for the standard curve. (A) Proportion of dead and viable cell for th primer. (B) Proportion of dead and viable cell for tdh primer. (C) Proportion of dead and viable cell for ureR primer.

Ct difference that is result of Ct value of the viable cell with PMA treatment minus the $\mathrm{Ct}$ value of the same concentration dead cell with PMA treatment. The results of experiments indicated that using of shrimp and clam tissue matrix spiked with purified DNA did not affect the sensitivity of detection, which were about one $\mathrm{Ct}$ value more than those obtained with the blank control.
Also, water sample spiked with purified DNA had little influence with $<1 \mathrm{Ct}$ value. This suggested that the presence of sample homogenate either had no inhibition or had a too small inhibition on the sensitivity of detection.

As shown in Figure 4, we could disclose that $V$. parahaemolyticus contamination rate in shrimp in Baoshan 


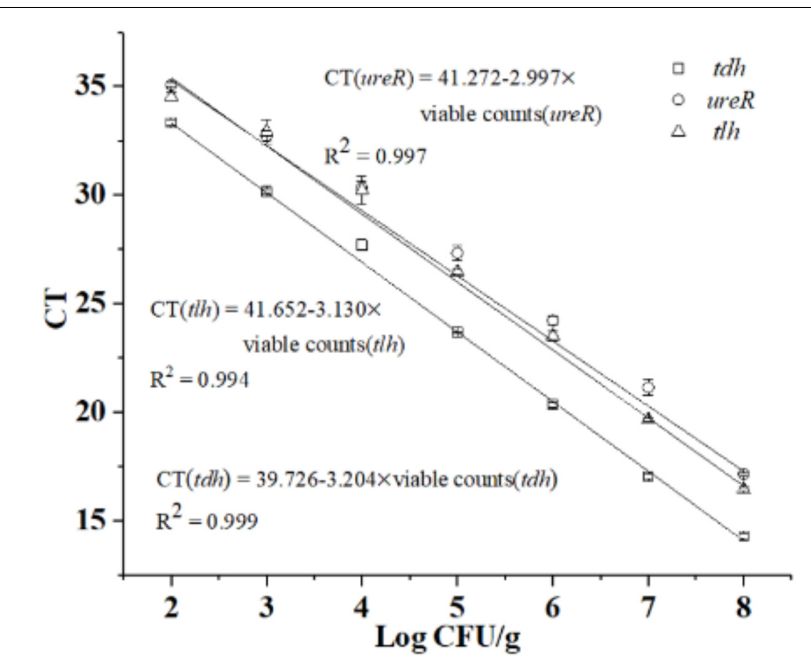

FIGURE 3 | Standard curves of th, tdh, and ureR in novel qPCR.

TABLE 3 | Comparison between novel PCR and traditional coating counting method.

\begin{tabular}{|c|c|c|c|}
\hline $\begin{array}{l}\text { Different } \\
\text { genes }\end{array}$ & $\begin{array}{c}\text { Inoculated } \\
\text { concentration } \\
\text { (CFU/g) }\end{array}$ & $\begin{array}{l}\text { Plate counting } \\
\text { results (log } \\
\text { CFU/g) }\end{array}$ & $\begin{array}{c}\text { PCR results (log } \\
\text { CFU/g) }\end{array}$ \\
\hline \multirow[t]{7}{*}{$\operatorname{tlh}^{+}$} & $10^{8}$ & $8.54 \pm 0.45$ & $8.31 \pm 0.09$ \\
\hline & $10^{7}$ & $7.38 \pm 0.18$ & $7.28 \pm 0.00$ \\
\hline & $10^{6}$ & $6.43 \pm 0.42$ & $6.57 \pm 0.03$ \\
\hline & $10^{5}$ & $5.19 \pm 0.61$ & $5.39 \pm 0.01$ \\
\hline & $10^{4}$ & $4.14 \pm 0.32$ & $4.26 \pm 0.01$ \\
\hline & $10^{3}$ & $3.24 \pm 0.25$ & $3.27 \pm 0.09$ \\
\hline & $10^{2}$ & $2.04 \pm 0.43$ & $2.23 \pm 0.12$ \\
\hline \multirow[t]{7}{*}{$t d h^{+}$} & $10^{8}$ & $8.45 \pm 0.33$ & $8.16 \pm 0.03$ \\
\hline & $10^{7}$ & $7.12 \pm 0.51$ & $7.00 \pm 0.01$ \\
\hline & $10^{6}$ & $6.33 \pm 0.61$ & $6.29 \pm 0.05$ \\
\hline & $10^{5}$ & $5.26 \pm 0.42$ & $5.49 \pm 0.02$ \\
\hline & $10^{4}$ & $4.36 \pm 0.53$ & $4.30 \pm 0.05$ \\
\hline & $10^{3}$ & $3.27 \pm 0.24$ & $3.53 \pm 0.06$ \\
\hline & $10^{2}$ & $2.02 \pm 0.12$ & $2.37 \pm 0.06$ \\
\hline \multirow[t]{7}{*}{ ureR $^{+}$} & $10^{8}$ & $8.51 \pm 0.29$ & $8.71 \pm 0.09$ \\
\hline & $10^{7}$ & $7.41 \pm 0.53$ & $7.67 \pm 0.01$ \\
\hline & $10^{6}$ & $6.17 \pm 0.24$ & $6.56 \pm 0.04$ \\
\hline & $10^{5}$ & $5.10 \pm 0.21$ & $5.24 \pm 0.02$ \\
\hline & $10^{4}$ & $4.27 \pm 0.22$ & $4.17 \pm 0.04$ \\
\hline & $10^{3}$ & $3.17 \pm 0.34$ & $2.96 \pm 0.04$ \\
\hline & $10^{2}$ & $1.92 \pm 0.47$ & $2.20 \pm 0.07$ \\
\hline
\end{tabular}

District was as high as $7 \mathrm{log}$, and the contamination rate in clam was as high as $6 \mathrm{log}$, which was the highest detection rate in all District. This indicated that these products might pose a risk to consumer when processed with no adequate cooking or eaten in unprocessed state (Zhang et al., 2017).

On the contrary, the contamination rate of $V$. parahaemolyticus detected in Main urban District was lower than other districts, and the viable bacteria were not found in the water samples (it may be lower than LOD). Moreover, contamination rate of $V$. parahaemolyticus in the corresponding water sample is in accordance with the contamination rate of the sample. Interestingly, no-pathogenic $V$. parahaemolyticus was found in all regions, which is consistent with previous reports that the aquatic products in market do not burden a great infection risk (Zhang et al., 2015a).

\section{DISCUSSION}

Microbiological detection and quantification technique had aroused our interest, especially when some sporadic epidemics or pandemic disease caused by pathogens. As shown in Supplementary Table S2 and Table 4, time-consuming, low sensitivity, complicated operation, and labor-consuming impeded the progress of traditional methods, on the contrary, PCR based method endowed with better sensitivity, higher throughput and specificity had been popular among researchers. To circumvent the variation of trh strains, ure $\mathrm{R}$ was used in this study. Additionally, innovative means by using two reaction tubes were put forward to overcome the complex logical relationship between $t h, t d h$, and $t r h$. Viable qPCR is a typically essential requirement especially when we need to detect and investigate the pathogens which are just present in low amount.

When it comes to the quantitative technique for viable cell, the difficulties of RNA extraction, and the rapid degradation of RNA hindered its application (Bleve et al., 2003; Morin et al., 2004). As for nucleic acid dyes, EMA, the inability to selectively detect viable cells was the most important obstacle impeding the application (Kobayashi et al., 2009; Yang et al., 2011; Fittipaldi et al., 2012). PMA combined with qPCR had been constructed for simultaneous detection and quantification of viable $V$. parahaemolyticus. The impact of rotation rate on PMA treatment was mentioned for the first time in this study, and the usage of PMA was reduced to $15 \mu \mathrm{M}$, which is much smaller than the previous report (Zhang et al., 2015a) and results in low detection costs. We have shortened the PMA optimization treatment by $20 \mathrm{~min}$, which was lower than many other studies (Xiao et al., 2015; Zhang et al., 2015a). It is very important for the government to make a quick respond and give a crucial decisionmaking in a short time especially after the sudden outbreak of disease caused by pathogens.

As shown in Table 3, there is a little discrepancy between the novel qPCR and traditional standard method, even though some studies already indicated the consistencies between them (Xiao et al., 2015; Zhang et al., 2015a). Apart from the experimental error, some scenarios still should be taken into account, because the results of PCR are higher than the plate counting. The cells in VBNC state and presence of sublethal cells should be addressed this query. The VBNC cells cannot be cultured in selective medium, however, they could be amplified by PCR. In addition, although some sublethal cells lose the ability to colony and growth, they still have metabolic activity, gene expression, and pathogenicity with membrane integrity (Lleó et al., 1998; Del Mar Lleo et al., 2007). Higher viable cell enumeration by PCR was observed in the first scenario results, whereas the second generates higher enumeration on plate counting. The incubation 

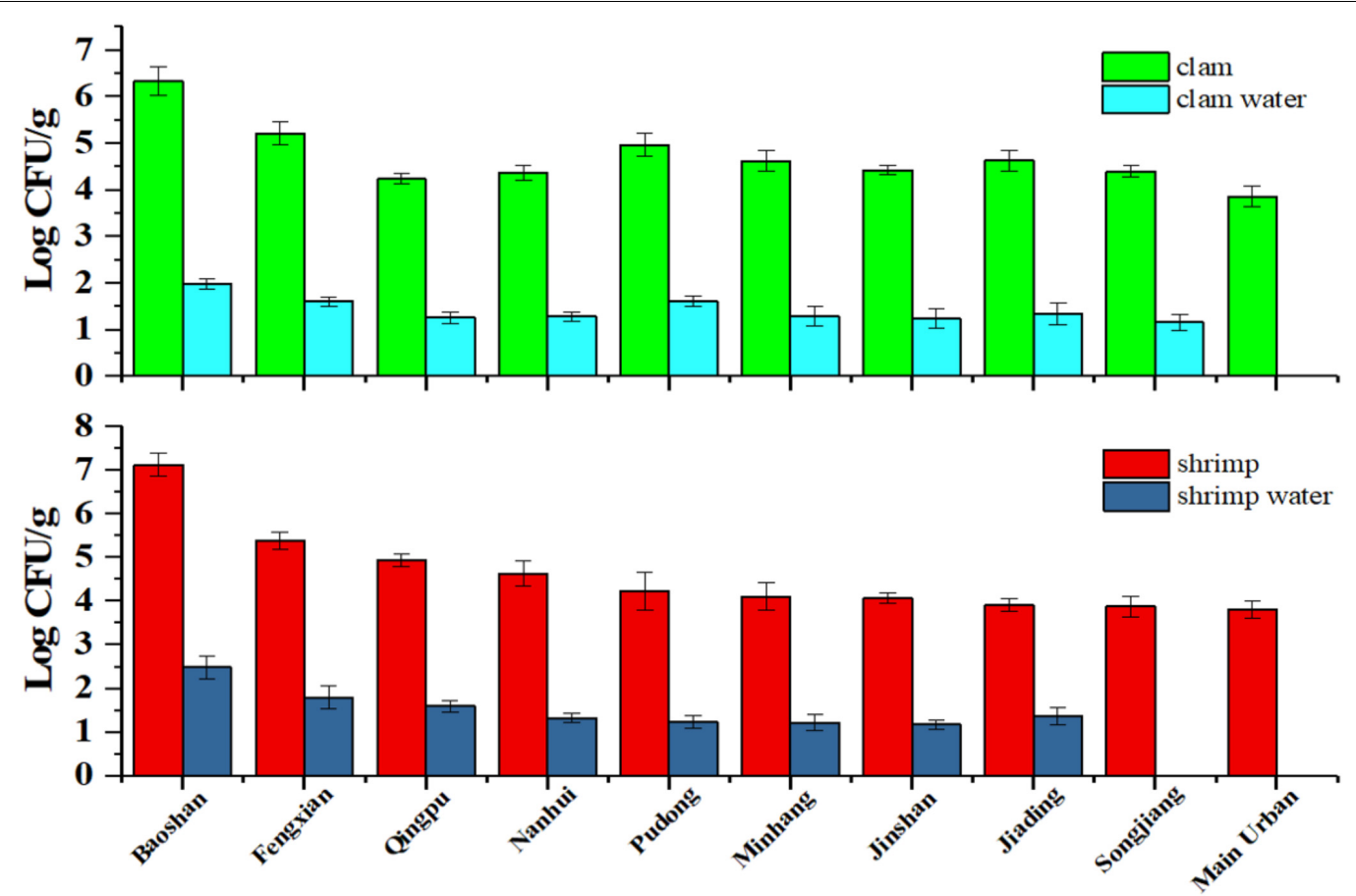

FIGURE 4 | The V. parahaemolyticus detection results of shrimp and clam and its water sample collected from retail stores in Shanghai.

TABLE 4 | Comparison between novel PCR and other method.

\begin{tabular}{|c|c|c|c|c|c|c|}
\hline \multirow[t]{2}{*}{ References } & \multicolumn{3}{|c|}{ Pretreatment } & \multirow[t]{2}{*}{ Reaction time } & \multirow{2}{*}{$\begin{array}{l}\text { Discrimination on } \\
\text { pathogenicity of V. P }\end{array}$} & \multirow[t]{2}{*}{ Remarks } \\
\hline & Dye style & Reagent dosage & Treatment time & & & \\
\hline Bej et al., 1999 & / & / & / & $1 \mathrm{~h} 33 \mathrm{~min}$ & tlh, tdh, trh & $\begin{array}{l}\text { It is a comprehensive detection of } \\
V . \text { parahaemolyticus in selfish. }\end{array}$ \\
\hline Garrido et al., 2012 & / & / & / & $55.5 \min$ & $t d h, \operatorname{trh} 1, \operatorname{trh} 2$ & $\begin{array}{l}\text { It is a detection only for pathogenic } \\
\text { V. parahaemolyticus. }\end{array}$ \\
\hline Robert-Pillot et al., 2010 & / & / & / & / & $\mathrm{R} 72 \mathrm{H}, t d h, t r h$ & $\begin{array}{l}\text { Different reaction conditions were } \\
\text { conducted on three target gene. }\end{array}$ \\
\hline Eschbach et al., 2017 & / & / & / & $1 \mathrm{~h} 2 \mathrm{~min}$ & th $, t d h, t r h 1$, trh2 & $\begin{array}{l}\text { V. parahaemolyticus, } V \text {. cholerae and } \\
\text { V. vulnifcus were only conducted in } \\
\text { interlaboratory study. }\end{array}$ \\
\hline Takahashi et al., 2005 & / & / & / & $1 \mathrm{~h} 8 \mathrm{~min}$ & toxR, tdh, trh & $\begin{array}{l}\text { It has been employed in pure culture, } \\
\text { seawater, and shellfish. }\end{array}$ \\
\hline Zhang et al., 2015b & / & / & / & $52 \min$ & th & $\begin{array}{l}\text { V. parahaemolyticus, L. monocytogenes, } \\
\text { and Salmonella spp. }\end{array}$ \\
\hline Panicker et al., 2004 & / & / & / & $1 \mathrm{~h} 3 \mathrm{~min}$ & tlh, tdh, trh, ORF8 & $\begin{array}{l}\text { V. vulnificus, V. parahaemolyticus, and } \\
\text { V. cholerae. }\end{array}$ \\
\hline Lee and Levin, 2009 & EMA & $2.381 \mu \mathrm{M}$ & $15 \min$ & $1 \mathrm{~h} 35 \mathrm{~min}$ & / & V. vulnificus. \\
\hline Zhang et al., 2015a & PMA & $100 \mu \mathrm{M}$ & $30 \mathrm{~min}$ & $52 \min$ & th & $\begin{array}{l}\text { V. parahaemolyticus and } \\
\text { L. monocytogenes }\end{array}$ \\
\hline This study & PMA & $15 \mu \mathrm{M}$ & $20 \min$ & $34 \min$ & th, tdh, ureR & $\begin{array}{l}\text { The ureR was based on Nilsson and } \\
\text { Turner (2016). }\end{array}$ \\
\hline
\end{tabular}

time in recovery medium might explain this phenomenon. Before coating on agar, comparing to longer time in recovery medium, a short incubation could reduce the discrepancy (Andorrà et al., 2010; Shi et al., 2011). Long enough incubation times allowed the sublethal cell recover in favorable condition, and the viable cell might divide.
There was a discrepancy between seafood sample and its corresponding water sample when the PCR inhibition experiment was conducted. Compared with water sample, seafood sample had a higher inhibition effect on PCR, which might be caused by the complexity culture matrix (Wagner et al., 2008; Varma et al., 2009). Interestingly, the clam sample had a 
great inhibition effect than shrimp, which was similar to previous finding reported by Umeda and Yoshinaga (2012). We speculated that more mineral such as various metal ions might be enriched by clam, which has a stronger effect on PCR reaction.

During the process of practical sample detection, pathogenic $V$. parahaemolyticus was not found in any samples, which indicated that the seafood in Shanghai market has little infection risk for people (Zhang et al., 2017). Of all sample collected in Shanghai, Baoshan had a highest $V$. parahaemolyticus contamination level, while $V$. parahaemolyticus contamination level in Main urban District was lower than other districts. The low contamination level in Main urban District might be caused by more strict regulations and supervisions. It was clearly seen that there were a lower detection results in the water sample when the counterpart seafood sample had a lower $V$. parahaemolyticus contamination level. Thus, we suggested that the detection of water sample could be reflect the contamination level of practical sample.

Being an important tool, microbiological rapid detection technique is indispensable for the government department after the outbreak of disease and also reliable for disease prevention and control. Furthermore, it is also very necessary for company to make policy decision of production, especially, the Hazard Analysis and Critical Control Point (HACCP) and Quantitative microbiological risk (QMRA) (Notermans et al., 1994; WHO Food Safety Programme, 2002). Finally, the method has been successfully applied to the detection of practical samples, providing a scientific tool for public health and safety.

\section{REFERENCES}

Andorrà, I., Estevezarzoso, B., Guillamón, J. M., and Mas, A. (2010). Determination of viable wine yeast using DNA binding dyes and quantitative PCR. Int. J. Food Microbiol. 144, 257-262. doi: 10.1016/j.ijfoodmicro.2010.10.003

Bej, A. K., Patterson, D. P., Brasher, C. W., Vickery, M. C. L., Jones, D. D., and Kaysner, C. A. (1999). Detection of total and hemolysin-producing Vibrio parahaemolyticus in shellfish using multiplex PCR amplification of $\mathrm{tl}$, tdh and trh. J. Microbiol. Methods 36, 215-225. doi: 10.1016/S0167-7012(99) 00037-8

Bisha, B., Simonson, J., Janes, M., Bauman, K., and Goodridge, L. D. (2012). A review of the current status of cultural and rapid detection of Vibrio parahaemolyticus. Int. J. Food Sci. Technol. 47, 885-899. doi: 10.1111/j.13652621.2012.02950.x

Bleve, G., Rizzotti, L., Dellaglio, F., and Torriani, S. (2003). Development of reverse transcription (RT)-PCR and real-time RT-PCR assays for rapid detection and quantification of viable yeasts and molds contaminating yogurts and pasteurized food products. Appl. Environ. Microbiol. 69, 4116-4122. doi: 10. 1128/AEM.69.7.4116-4122.2003

Ceccarelli, D., Hasan, N. A., Huq, A., and Colwell, R. R. (2013). Distribution and dynamics of epidemic and pandemic Vibrio parahaemolyticus virulence factors. Front. Cell. Infect. Microbiol. 3:97. doi: 10.3389/fcimb.2013.00097

Chang, B., Taguri, T., Sugiyama, K., Amemuramaekawa, J., Kura, F., and Watanabe, H. (2010). Comparison of ethidium monoazide and propidium monoazide for the selective detection of viable Legionella cells. Jpn. J. Infect. Dis. 63, 119-123.

Coutard, F., Crassous, P., Droguet, M., Gobin, E., Colwell, R. R., Pommepuy, M., et al. (2007). Recovery in culture of viable but nonculturable Vibrio parahaemolyticus: regrowth or resuscitation? Isme J. 1, 111-120. doi: 10.1038/ ismej.2007.1

\section{AUTHOR CONTRIBUTIONS}

YZ, YP, and HL conceived and supervised the study. BN, BH, and $\mathrm{ZZ}$ designed the experiments. $\mathrm{BN}, \mathrm{BH}$, and $\mathrm{LM}$ performed the experiments. $\mathrm{BN}, \mathrm{BH}, \mathrm{LM}$, and $\mathrm{ZZ}$ analyzed the data. $\mathrm{BN}, \mathrm{ZZ}$, $\mathrm{PM}$, and $\mathrm{YZ}$ revised the paper. BN wrote the paper.

\section{FUNDING}

This research was supported by the Innovation Program of Shanghai Municipal Education Commission (2017-01-07-00-10E00056), the National Natural Science Foundation of China (31571917 and 31671779), Key Project of Shanghai Agriculture Prosperity through Science and Technology (Grant: 2015, 4-8 and 2016, 1-1), and the "Dawn" Program of Shanghai Education Commission (15SG48).

\section{ACKNOWLEDGMENTS}

We are grateful to Qiao Han, Fei Zhao, Jiangping Sun, and Weiqi Liu who gave us many advices when we wrote the manuscript.

\section{SUPPLEMENTARY MATERIAL}

The Supplementary Material for this article can be found online at: https://www.frontiersin.org/articles/10.3389/fmicb. 2018.01747/full\#supplementary-material

Del Mar Lleo, M., Benedetti, D., Tafi, M. C., Signoretto, C., and Canepari, P. (2007). Inhibition of the resuscitation from the viable but non-culturable state in Enterococcus faecalis. Environ. Microbiol. 9, 2313-2320. doi: 10.1111/j.14622920.2007.01345.x

Eschbach, E., Martin, A., Huhn, J., Seidel, C., Heuer, R., Schumacher, J. H., et al. (2017). Detection of enteropathogenic Vibrio parahaemolyticus, Vibrio cholerae and Vibrio vulnificus: performance of real-time PCR kits in an interlaboratory study. Eur. Food Res. Technol. 243, 1335-1342. doi: 10.1007/s00217-0172844-Z

Fittipaldi, M., Nocker, A., and Codony, F. (2012). Progress in understanding preferential detection of live cells using viability dyes in combination with DNA amplification ${ }^{3}$. J. Microbiol. Methods 91, 276-289. doi: 10.1016/j.mimet.2012. 08.007

Garrido, A., Chapela, M. J., Ferreira, M., Atanassova, M., Fajardo, P., Lago, J., et al. (2012). Development of a multiplex real-time PCR method for pathogenic Vibrio parahaemolyticus detection (tdh+ and trh+). Food Control 24, 128-135. doi: 10.1016/j.foodcont.2011.09.015

Gonzálezescalona, N., Hammack, T. S., Russell, M., Jacobson, A. P., Jesús, A. J. D., Brown, E. W., et al. (2009). Detection of live Salmonella spp. cells in produce by a TaqMan-based quantitative reverse transcriptase real-time PCR targeting invA mRNA. Appl. Environ. Microbiol. 75, 3714-3720. doi: 10.1128/AEM. 02686-08

Honda, T., Ni, Y., and Miwatani, T. (1989). Purification of a TDHrelated hemolysin produced by a Kanagawa phenomenon-negative clinical isolate of Vibrio parahaemolyticus 06: K46. FEMS Microbiol. Lett. 57, 241-245.

Honda, T., Ni, Y. X., and Miwatani, T. (1988). Purification and characterization of a hemolysin produced by a clinical isolate of Kanagawa phenomenon-negative Vibrio parahaemolyticus and related to the thermostable direct hemolysin. Infect. Immun. 56, 961-965. 
Hondo, S., Goto, I., Minematsu, I., Ikeda, N., Asano, N., Ishibashi, M., et al. (1987). Gastroenteritis due to Kanagawa negative Vibrio parahaemolyticus. Lancet 1, 331-332. doi: 10.1016/S0140-6736(87)92062-9

Kaper, J. B., Campen, R. K., Seidler, R. J., Baldini, M. M., and Falkow, S. (1984). Cloning of the thermostable direct or Kanagawa phenomenon-associated hemolysin of Vibrio parahaemolyticus. Infect. Immun. 45, 290-292.

Kobayashi, H., Oethinger, M., Tuohy, M. J., Hall, G. S., and Bauer, T. W. (2009). Improving clinical significance of PCR: use of propidium monoazide to distinguish viable from dead Staphylococcus aureus and Staphylococcus epidermidis. J. Orthop. Res. 27, 1243-1247. doi: 10.1002/jor.20872

Lee, J. L., and Levin, R. E. (2009). A comparative study of the ability of EMA and PMA to distinguish viable from heat killed mixed bacterial flora from fish fillets. J. Microbiol. Methods 76, 93-96. doi: 10.1016/j.mimet.2008.08.008

Letchumanan, V., Pusparajah, P., Tan, T. H., Yin, W. F., Lee, L. H., and Chan, K. G. (2015). Occurrence and antibiotic resistance of Vibrio parahaemolyticus from shellfish in Selangor, Malaysia. Front. Microbiol. 6:1417. doi: 10.3389/fmicb. 2015.01417

Li, B., and Chen, J. Q. (2013). Development of a sensitive and specific qPCR assay in conjunction with propidium monoazide for enhanced detection of live Salmonella spp. in food. BMC Microbiol. 13:273. doi: 10.1186/1471-2180-13-273

Li, H., Tang, R., Lou, Y., Cui, Z., Chen, W., Hong, Q., et al. (2017). A comprehensive epidemiological research for clinical Vibrio parahaemolyticus in Shanghai. Front. Microbiol. 8:1043. doi: 10.3389/fmicb.2017.01043

Li, H., Xin, H., and Li, S. F. (2015). Multiplex PMA-qPCR assay with internal amplification control for simultaneous detection of viable Legionella pneumophila, Salmonella Typhimurium, and Staphylococcus Aureus in environmental waters. Environ. Sci. Technol. 49, 14249-14256. doi: 10.1021/acs. est. 5 b03583

Lleó, M. M., Tafi, M. C., and Canepari, P. (1998). Nonculturable Enterococcus faecalis cells are metabolically active and capable of resuming active growth. Syst. Appl. Microbiol. 21, 333-339. doi: 10.1016/S0723-2020(98)80041-6

Løvdal, T., Hovda, M. B., Björkblom, B., and Møller, S. G. (2011). Propidium monoazide combined with real-time quantitative PCR underestimates heatkilled Listeria innocua. J. Microbiol. Methods 85, 164-169. doi: 10.1016/j.mimet. 2011.01.027

Miller, N. D., Davidson, P. M., and D'Souza, D. H. (2011). Real-time reversetranscriptase PCR for Salmonella Typhimurium detection from lettuce and tomatoes. LWT Food Sci. Technol. 44, 1088-1097. doi: 10.1016/j.lwt.2010.08.003

Morin, N. J., Gong, Z., and Li, X. F. (2004). Reverse transcription-multiplex PCR assay for simultaneous detection of Escherichia coli O157:H7, Vibrio cholerae O1, and Salmonella Typhi. Clin. Chem. 50, 2037-2044. doi: 10.1373/clinchem. 2004.036814

Nilsson, W. B., and Turner, J. W. (2016). The thermostable direct hemolysinrelated hemolysin (trh) gene of Vibrio parahaemolyticus: sequence variation and implications for detection and function. J. Microbiol. Methods 126, 1-7. doi: 10.1016/j.mimet.2016.04.007

Nishibuchi, M., and Kaper, J. B. (1990). Duplication and variation of the thermostable direct haemolysin (tdh) gene in Vibrio parahaemolyticus. Mol. Microbiol. 4, 87-99. doi: 10.1111/j.1365-2958.1990.tb02017.x

Nishibuchi, M., Taniguchi, T., Misawa, T., Khaeomaneeiam, V., Honda, T., and Miwatani, T. (1989). Cloning and nucleotide sequence of the gene (trh) encoding the hemolysin related to the thermostable direct hemolysin of Vibrio parahaemolyticus. Infect. Immun. 57, 2691-2697.

Niu, B., Mu, L., Xiao, L., Zhang, Z., Malakar, P. K., Liu, H., et al. (2018). Reduction of infection risk meditated by co-culturing Vibrio parahaemolyticus and Listeria monocytogenes in refrigerated cooked shrimp. J. Sci. Food Agric. doi: 10.1002/ jsfa.8969 [Epub ahead of print].

Nordin, N., Yusof, N. A., Abdullah, J., Radu, S., and Hushiarian, R. (2017). A simple, portable, electrochemical biosensor to screen shellfish for Vibrio parahaemolyticus. AMB Express 7:41. doi: 10.1186/s13568-017-0339-8

Nordstrom, J. L., Vickery, M. C. L., Blackstone, G. M., Murray, S. L., and DePaola, A. (2007). Development of a multiplex real-time PCR assay with an internal amplification control for the detection of total and pathogenic Vibrio parahaemolyticus bacteria in oysters. Appl. Environ. Microbiol. 73, 5840-5847. doi: 10.1128/aem.00460-07

Notermans, S., Gallhoff, G., Zwietering, M. H., and Mead, G. C. (1994). The HACCP concept: specification of criteria using quantitative risk assessment ${ }^{* *}$. Food Microbiol. 12, 81-90. doi: 10.1016/S0740-0020(95)80082-4
Pan, Y., and Breidt, F. (2007). Enumeration of viable Listeria monocytogenes cells by real-time PCR with propidium monoazide and ethidium monoazide in the presence of dead cells. Appl. Environ. Microbiol. 73, 8028-8031. doi: 10.1128/ AEM.01198-07

Panicker, G., Call, D. R., Krug, M. J., and Bej, A. K. (2004). Detection of pathogenic Vibrio spp. in shellfish by using multiplex PCR and DNA microarrays. Appl. Environ. Microbiol. 70, 7436-7444. doi: 10.1128/AEM.70.12.7436-7444. 2004

Robert-Pillot, A., Copin, S., Gay, M., Malle, P., and Quilici, M. L. (2010). Total and pathogenic Vibrio parahaemolyticus in shrimp: fast and reliable quantification by real-time PCR. Int. J. Food Microbiol. 143, 190-197. doi: 10.1016/j.ijfoodmicro.2010.08.016

Salam, K. W., El-Fadel, M., Barbour, E. K., and Saikaly, P. E. (2014). A propidium monoazide-quantitative PCR method for the detection and quantification of viable Enterococcus faecalis in large-volume samples of marine waters. Appl. Microbiol. Biotechnol. 98, 8707-8718. doi: 10.1007/s00253-0146023-x

Shi, H., Xu, W., Luo, Y., Chen, L., Liang, Z., Zhou, X., et al. (2011). The effect of various environmental factors on the ethidium monazite and quantitative PCR method to detect viable bacteria. J. Appl. Microbiol. 111, 1194-1204. doi: 10.1111/j.1365-2672.2011.05125.x

Shinoda, S. (2011). Sixty years from the discovery of Vibrio parahaemolyticus and some recollections. Biocontrol Sci. 16, 129-137. doi: 10.4265/bio. 16.129

Soejima, T., Schlittdittrich, F., and Yoshida, S. (2011). Rapid detection of viable bacteria by nested polymerase chain reaction via long DNA amplification after ethidium monoazide treatment. Anal. Biochem. 418, 286-294. doi: 10.1016/j.ab. 2011.06.033

Su, Y. C., and Liu, C. (2007). Vibrio parahaemolyticus: a concern of seafood safety. Food Microbiol. 24, 549-558. doi: 10.1016/j.fm.2007.01.005

Suthienkul, O., Ishibashi, M., Iida, T., Nettip, N., Supavej, S., Eampokalap, B., et al. (1995). Urease production correlates with possession of the trh gene in Vibrio parahaemolyticus strains isolated in Thailand. J. Infect. Dis. 172, 1405-1408. doi: 10.1093/infdis/172.5.1405

Takahashi, H., Iwade, Y., Konuma, H., and Harakudo, Y. (2005). Development of a quantitative real-time PCR method for estimation of the total number of Vibrio parahaemolyticus in contaminated shellfish and seawater. J. Food Prot. 68, 1083-1088. doi: 10.4315/0362-028X-68.5.1083

Umeda, K., and Yoshinaga, T. (2012). Development of real-time PCR assays for discrimination and quantification of two Perkinsus spp. in the Manila clam Ruditapes philippinarum. Dis. Aquat. Organ. 99, 215-225. doi: 10.3354/ dao02476

Varma, M., Field, R., Stinson, M., Rukovets, B., Wymer, L., Haugland, R., et al. (2009). Quantitative real-time PCR analysis of total and propidium monoazideresistant fecal indicator bacteria in wastewater. Water Res. 43, 4790-4801. doi: 10.1016/j.watres.2009.05.031

Wagner, A. O., Malin, C., Knapp, B. A., and Illmer, P. (2008). Removal of free extracellular DNA from environmental samples by ethidium monoazide and propidium monoazide. Appl. Environ. Microbiol. 74, 2537-2539. doi: 10.1128/ AEM.02288-07

Wang, L. J., Ye, C. L., Xu, H. Y., Aguilar, Z. P., Xiong, Y. H., Lai, W. H., et al. (2015). Development of an SD-PMA-mPCR assay with internal amplification control for rapid and sensitive detection of viable Salmonella spp., Shigella spp. and Staphylococcus Aureus in food products. Food Control 57, 314-320. doi: 10.1016/j.foodcont.2015.04.016

Wang, R., Zhong, Y., Gu, X., Yuan, J., Saeed, A. F., and Wang, S. (2015). The pathogenesis, detection, and prevention of Vibrio parahaemolyticus. Front. Microbiol. 6:144. doi: 10.3389/fmicb.2015.00144

WHO Food Safety Programme (2002). WHO Global Strategy For Food Safety: Safer Food For Better Health. Geneva: World Health Organization.

Wu, W., Zhou, M., He, H., Liu, C., Li, P., Wang, M., et al. (2018). A sensitive aptasensor for the detection of Vibrio parahaemolyticus. Sens. Actuators B Chem. 272, 550-558. doi: 10.1016/j.snb.2018.05.171

Xiao, L., Zhang, Z., Sun, X., Pan, Y., and Zhao, Y. (2015). Development of a quantitative real-time PCR assay for viable Salmonella spp. without enrichment. Food Control 57, 185-189. doi: 10.1016/j.foodcont.2015.03.050

Yang, H. L., Wei, S., Gooneratne, R., Mutukumira, A. N., Ma, X. J., Tang, S. Z., et al. (2018). Development of a recombinase polymerase amplification assay for 
Vibrio parahaemolyticus detection with an internal amplification control. Can. J. Microbiol. 64, 223-230. doi: 10.1139/cjm-2017-0504

Yang, X., Badoni, M., and Gill, C. O. (2011). Use of propidium monoazide and quantitative PCR for differentiation of viable Escherichia coli from E. coli killed by mild or pasteurizing heat treatments. Food Microbiol. 28, 1478-1482. doi: 10.1016/j.fm.2011.08.013

Ye, K., Zhang, Q., Jiang, Y., Xu, X., Cao, J., and Zhoua, G. (2012). Rapid detection of viable Listeria monocytogenes in chilled pork by real-time reverse-transcriptase PCR. Food Control 25, 117-124. doi: 10.1016/j.foodcont.2011.10.025

Zhang, Z., Liu, H., Lou, Y., Xiao, L., Liao, C., Malakar, P. K., et al. (2015a). Quantifying viable Vibrio parahaemolyticus and Listeria monocytogenes simultaneously in raw shrimp. Appl. Microbiol. Biotechnol. 99, 6451-6462. doi: 10.1007/s00253-015-6715-x

Zhang, Z., Lou, Y., Du, S., Xiao, L., Niu, B., Pan, Y., et al. (2017). Prevalence of Vibrio parahaemolyticus in seafood products from hypermarkets in Shanghai. J. Sci. Food Agric. 97, 705-710. doi: 10.1002/jsfa.7715
Zhang, Z., Xiao, L., Lou, Y., Jin, M., Liao, C., Malakar, P. K., et al. (2015b) Development of a multiplex real-time PCR method for simultaneous detection of Vibrio parahaemolyticus, Listeria monocytogenes and Salmonella spp. in raw shrimp. Food Control 51, 31-36. doi: 10.1016/j.foodcont.2014.11.007

Conflict of Interest Statement: The authors declare that the research was conducted in the absence of any commercial or financial relationships that could be construed as a potential conflict of interest.

Copyright () $2018 \mathrm{Niu}$, Hong, Zhang, Mu, Malakar, Liu, Pan and Zhao. This is an open-access article distributed under the terms of the Creative Commons Attribution License (CC BY). The use, distribution or reproduction in other forums is permitted, provided the original author(s) and the copyright owner(s) are credited and that the original publication in this journal is cited, in accordance with accepted academic practice. No use, distribution or reproduction is permitted which does not comply with these terms. 